\title{
SOCIAL J USTICE IN THE FOREST: Aboriginal engagement with Australia's forest industries
}

\author{
Transforming Cultures eJ ournal, \\ Vol. 3 No 1, February 2008 \\ http:// epress.lib.uts.edu.au/journals/TfC
}

Sue Feary ${ }^{1}$

\begin{abstract}
What remains of Australia's native forests are important to Aboriginal people for environmental, cultural and economic reasons. Managers of forests in protected areas at State and Commonwealth levels have policies for involving Aboriginal people in forest management and for protecting the intangible and tangible values that Aboriginal people place on forests, but there are limited opportunities for significant economic returns to Aboriginal communities. Outside of conservation reserves, there are native timber production forests on crown land, plantations on private and public land and, forests on Aboriginal land, that offer a range of opportunities for Aboriginal people to engage with forest industries. Cultural traditions and values continue to play a role but they are manifest in different ways, depending on the local situation.
\end{abstract}

\section{Introduction}

The importance of the natural environment to the cultural identity and social wellbeing of Aboriginal Australians is well known (Rose, 1996). Since the referendum of 1967, ${ }^{2}$ the unique connection between Aboriginal people and the land has been recognised in social justice and reconciliation movements as well as in law through state and territory land rights legislation and federal native title legislation. The majority of Australia’s 'natural'3 environment, whether forests, mangroves or desert, is in public ownership,

\footnotetext{
${ }^{1}$ Sue Feary is an Archaeologist for the Environmental Protection and Regulation Division, Department of Environment and Conservation.

2 The constitutional amendment of 1967 was supported by all major political parties and over $90 \%$ of Australians. It opened the way for Aboriginal people to be included in the census and for the Commonwealth to take a more active role in Aboriginal affairs nation-wide. It was followed in 1972 by the introduction of policies for Aboriginal self-determination by the Whitlam Labor government.
}

${ }^{3} \mathrm{Natural} /$ naturalness is a contested term in discourses on nature conservation. Most 'natural' areas contain evidence of human endeavours for example, Aboriginal occupation, selective logging, early mining, rural settlements, pastoralism and agriculture, exploration, construction of transport routes, that 
although the expanding Aboriginal-owned estate (Pollack, 2001) is now incorporating large tracts of land with conservation values (Altman and Hinkson, 2007). Land management agencies at both federal and state levels are generally supportive of Aboriginal people's desire to maintain physical and emotional connections with the natural environment and have adopted policies for facilitating access for cultural activities, providing employment opportunities and encouraging partnerships in land management. Despite these efforts, as well as numerous government funded social welfare programmes and the existence since 1992, of common law recognition of native title, Aboriginal people remain the most economically and socially disadvantaged group in Australia - a third world people living in the first world (Young, 1995).

But social wellbeing of Aboriginal people is not solely dependent on maintaining cultural identity and connecting with ancestral landscapes. Like all human beings in today's modern capitalist society, Aboriginal people's wellbeing is also a product of their financial status. In the case of Aboriginal people, the financial situations of individuals, families and whole communities are invariably interrelated, so loss of a job or welfare payments affects not only the recipient but also the extended family that depends on him or her. Aboriginal leader Noel Pearson's vision for the future of his people of Cape York Peninsula in Far North Queensland recognises the importance of economic independence as the cornerstone of a viable Aboriginal culture (Pearson, 2005). Although accumulation of material or financial wealth may not be the primary objective of many Aboriginal people (Martin, 1995), there is no question that cash and the commodities it brings are intensely sought after (Trigger, 1997). However many Aboriginal people do not have the training or education necessary to get a foothold in the western economy. Additionally, many Aboriginal people make choices to stay on their land and remain in their communities rather than diminish these connections by moving away to find employment or establish business enterprises (Austin-Broos, 2005). Both these situations result in an increased dependency on welfare payments but in neither case do Aboriginal people choose the poverty and poor health often associated with welfare dependency.

may or may not be visible to the untrained eye. The National Wilderness Inventory has adopted a disturbance scale as a measure of the degree of naturalness.

(See <http://www.heritage.gov.au/anlr/nwi/handbook.html>). 
An ideal situation would seem to be to bring together the three important components of the Aboriginal domain - maintaining culture, connecting with the land and, attaining economic independence - in projects that involve working on country to achieve economic, social and environmental benefits (Baker et al., 2001). Natural resource management (NRM) programmes in general and conservation programmes in particular, have achieved some level of success in engaging Aboriginal people in land management through various participatory processes (Orchard et al., 2003). However, since NRM activities are largely outside the market economy they are unlikely to lead to major improvements in the economic circumstances of Aboriginal people, either collectively or as individuals.

This paper aims to demonstrate the potential capacity of another land management industry, the forestry industry, to contribute to meeting the three important goals in the Aboriginal domain. The paper draws on empirical information from two sources: recent social science research undertaken for my $\mathrm{PhD}$ at the Australian National University's Fenner School of Environment and Society ${ }^{4}$ and my experiences and reflections as a land manager and archaeologist working for a conservation agency, the NSW National Parks and Wildlife Service (NPWS) (now the NSW Department of Environment and Climate Change). The first section of the paper presents two vignettes that tease out some of the essential elements associated with Aboriginal people's attitudes towards western conservation practices while the second section focuses on forest-based economic activity.

\section{Forest conservation and Aboriginal people}

The two vignettes below give a glimpse into reasons behind Aboriginal people's attitudes towards conservation. Both set in southeastern NSW, the first concerns Aboriginal people's role in the anti-logging protests of the late 1980s while the second is centred on early attempts to create a jointly managed national park at Jervis Bay on the NSW south coast.

\footnotetext{
${ }^{4}$ The thesis explored the capacity of a broadly defined forest sector to contribute to alleviating Aboriginal social and economic disadvantage. Analysis of interviews and observations from four case studies representing a broad spectrum of Aboriginal involvement with the forest sector formed the basis for an 'alternative' National Indigenous Forestry Strategy to the one currently being implemented by the federal government.
} 


\section{Vignette One}

Logging operations to service a sawlog and woodchip industry have been occurring since the early 1970s in the eucalypt forests of southeastern NSW near Eden (Figure 1). The area has a history of intense citizen protests over clearing native forests to plant pine trees and over the impacts of intensive logging on the non-timber values of the forests. These forestry operations became the subject of the seminal and highly controversial publication The Fight for the Forests (Routley and Routley 1975), whose findings came to fundamentally change the way native forests were managed in Australia (Dargavel, 1995).

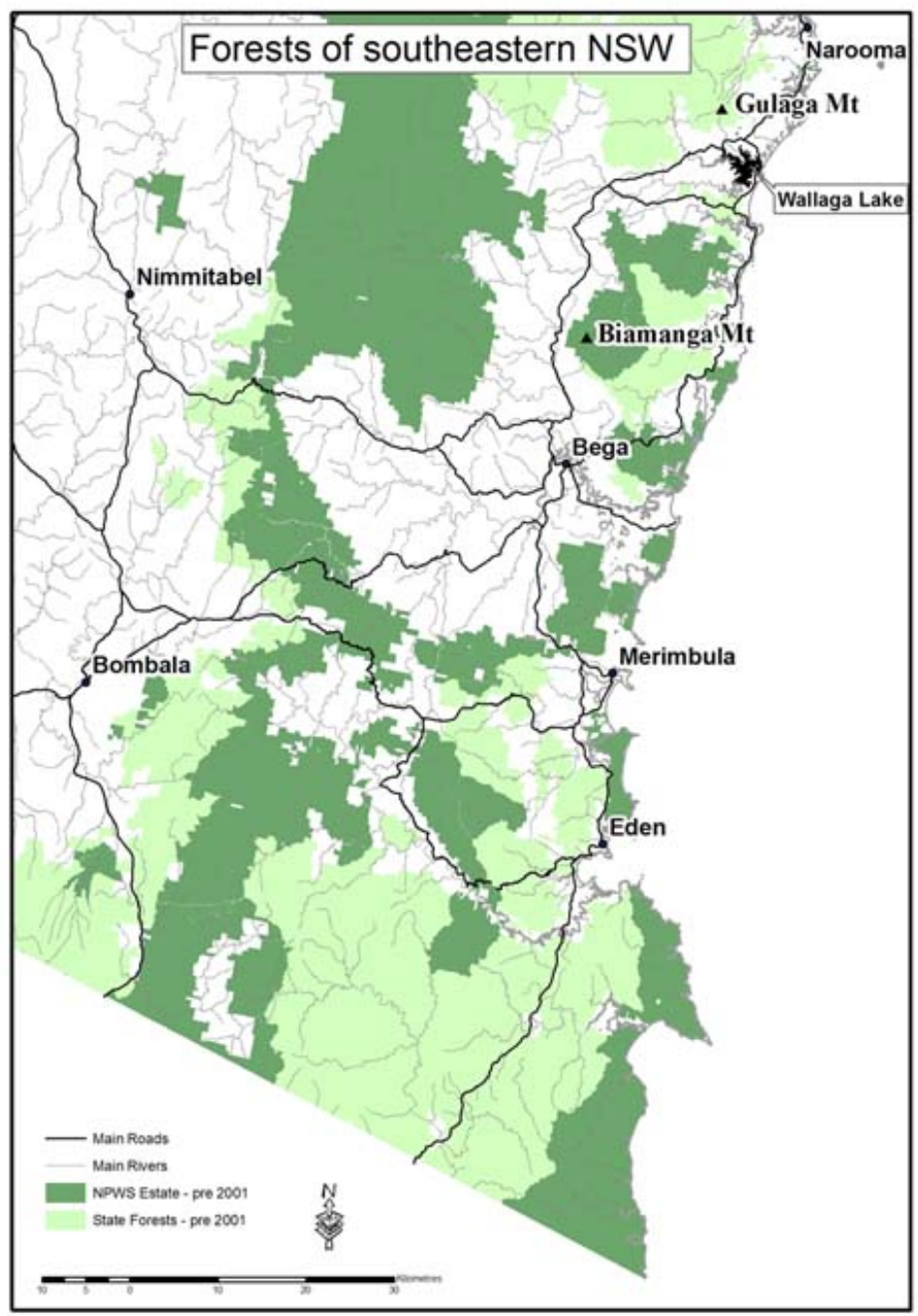

Figure 1: Forests of southeastern NSW.

In 1986 the NSW Forestry Commission released its draft Environmental Impact Statement (EIS) for the Eden export woodchip operation to meet government requirements for renewing the licence for woodchips to be exported to Japan (HarrisDaishowa Pty Ltd 1986). The (then) National Parks and Wildlife Service (NPWS) and 
environmental groups claimed the EIS was inadequate, primarily because forest management policies and procedures were based on very limited research into the habitat requirements of forest fauna and the impacts of logging on their ecology and behaviour (Lunney and Barker, 1986). Protests and campaigns escalated as conservation groups and NPWS pushed for an expanded conservation estate, resulting in scuffles between green groups, timber workers and the police. Numerous arrests were made and although not on the scale of protests at Terania Creek on the north coast in the 1970s (Turvey, 2006), the people involved were no less passionate in their views about protection of these magnificent ancient forests.

Aboriginal voices were notably absent in the voices raised against logging in the Eden forests. There is anecdotal evidence to suggest that conservation groups were surprised; having more or less assumed Aboriginal support for the campaign to protect the forests and their associated values, including their Aboriginal values. At the time I was employed as an Archaeologist with NPWS, undertaking archaeological surveys in the Eden Woodchip Agreement Area to provide data for a response to the Forestry Commission's EIS. I was also surprised, given the scale of protests by local Aboriginal elders in response to the Forestry Commission's logging of the sacred Mumbulla Mountain (Biamanga) in the late 1970s (Egloff, 1979) (see Fig. 1). Additionally, throughout the 1980s, a large number of studies into the Aboriginal cultural heritage of timber production forests had been commissioned by government agencies in most states e.g NSW (Bowdler, 1983), Tasmania (Cosgrove, 1990) and Western Australia (Anderson, 1984). Although these focused for the most part on archaeological sites, they did put forest managers on notice that Aboriginal people had a stake in forests that went beyond protecting archaeological sites.

Protests over forestry activities that were impacting both natural and cultural values seemed a fitting venue for Aboriginal people to add their voices, but during the protests in the Eden forests, some local Aboriginal men told me they would not publicly criticise 'the forestry' even though they knew logging operations were destroying Aboriginal heritage. They told me that during the 1950s and 1960s on the south coast, forestry was a major employer of Aboriginal people, in the sawmills and as fallers in the forests; they were 'friends of the Kooris', at a time when racism and inequality denied many Aboriginal people employment in the mainstream economy. 
Involvement of Aboriginal men in the timber industry was alluded to in an Aboriginal history of East Gippsland (Thompson, 1985) but the literature on Aboriginal people in the workforce of the NSW far south coast has little to say about it; the focus being primarily on bean and pea picking (Castel and Hagan, 1978). However, the oral history tells a vastly different story. Seminal historical and oral history research on the life of a south coast Aboriginal leader Percy Mumbulla (Chittick and Fox, 1997) and more recently regional cultural heritage studies undertaken by local and state governments ${ }^{5}$ provide a rich source of information on just how important the timber industry was to the livelihoods of local Aboriginal families. They give the impression that there was barely an Aboriginal family who did not have at least one of its men employed in one of the many sawmills. And, unlike bean and pea picking, which has left many negative memories of hard, poorly paid work riddled with discrimination and racism, references to working in the timber industry evoke neutral or positive memories:

My father worked in the sawmills and I went into the same game. It was the only thing at the time that we could get into apart from bean pickin'. The only job! As much as I loved the bush, I knew than that it was the only way to get some money. Workin’ in the sawmills we had a little freedom. I worked in the mills at Bombala, Adaminaby and a couple of others in Vic and up around Braidwood there. But I mainly kept to two mills, and that was Bombala and Adaminaby. I was good at my job, and they put me in charge and I was foreman and manager of both mills that I worked in. It's close to twenty-two years that I worked in the sawmills. Yeah, I built three mills, and made things easier for the fella that worked there, because its hard work in the sawmills. Pretty dangerous too! I've got a couple of scars on my fingers and I almost lost my hand. It was mainly blackfella that always worked the benches, you know. We never made it a chore and that was the beauty of workin' there. The Kooris that worked in the mill, they always sang, they were happy, you know. You could always hear the cooeein' out and the singin’ out over the buzz of the saws (Chittick and Fox, 1997:128129)

\footnotetext{
5 The Shoalhaven, Eurobodalla and Bega Valley Shire Councils, together with the Southern Rivers Catchment Management Authority, DECC and local Aboriginal people are preparing regional cultural heritage studies to enable shire land planning to be more cognisant of Aboriginal culture and history. These comprise archival, oral history and archaeological research using principles of Participatory Action Research. The oral history component is proving invaluable as a source on information on Aboriginal employment in the timber industry during the mid $20^{\text {th }}$ century.
} 
The sentiments expressed in this excerpt from an interview with an Aboriginal man from Wallaga Lake, Max Harrison, is indicative of numerous references to working in the timber industry that emerged during current oral history research on the NSW far south coast (Goulding and Waters, 2005; Goulding and Waters, 2004; Donaldson, 2006; Goulding and Griffiths, 2004). It is interesting to note that at a time when protests were occurring over payment of equal wages in the pastoral industry, leading to the landmark walk-off from Wave Hill Station by the Gurindji people in 1966 (Rowley, 1970), Aboriginal men on the south coast were picking and choosing what sawmills they worked in, based on the wages that were being offered:

Koori people liked working at Stony Creek for Davis and Herbert because they paid proper wages [interview with Alex Walker (Donaldson, 2006:96)]

An awareness of the role that the timber industry played in the lives of recent generations of Aboriginal people on the south coast gives an understanding of their reluctance to publicly condemn contemporary forestry management practices. But reluctance to support the conservation movement was also the result of a much longer history of forest management premised on an Aboriginal worldview sometimes at odds with western notions of conservation that leads into the second vignette.

\section{Vignette Two}

The second vignette is about differences between Aboriginal and non-Aboriginal values of the natural landscape. The coastal eucalypt forests, Banksia woodlands, wetlands, rainforest patches and coastal heaths at Jervis Bay on the NSW south coast approximately $200 \mathrm{~km}$ south of Sydney (Figure 2) are renowned for their outstanding nature conservation values, including great biodiversity, presence of rare and endangered species of flora and fauna and their aesthetic beauty (Kristo, nd). For decades conservation groups have campaigned for the area to be declared a national park, which together with what is now Booderee National Park in Commonwealth Territory to the south, would fully protect the catchment of the bay. Calls to declare the national park intensified in 1992 when the Commonwealth Government announced its 
intention to relocate the Navy's fleet base and armaments depot from Sydney Harbour to Jervis Bay.

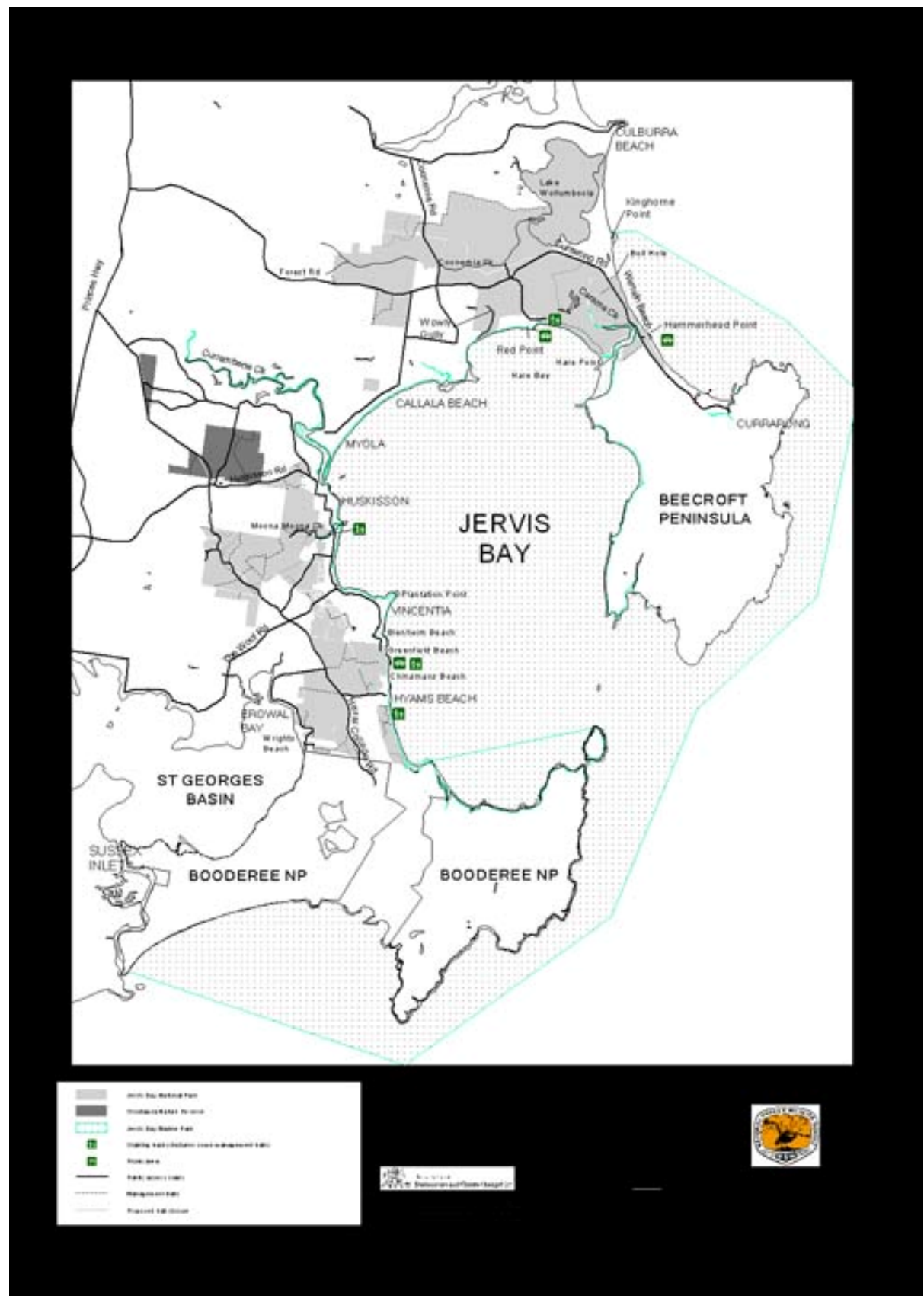

Figure 2: Marine and national parks of jervis Bay (Jervis Bay NP is coloured light grey).

In this instance local Aboriginal people joined with conservation groups in their opposition to the proposal (Lowe and Davies, 2001). For, as well as its nature conservation values, the landscapes of Jervis Bay and in particular Beecroft Peninsula are deeply imbued with meaning for Aboriginal people. The land and waters of Jervis 
Bay are a sentient being, linking the past with the present, through creation stories, song lines and memories about places of ceremony, ritual and everyday life. Many of these traditional places are still in use ${ }^{6}$ and Jervis Bay is a rare example in 'settled' Australia of unbroken connections between Aboriginal people and their country, from thousand of years ago, surviving policies of exclusion in missions and then assimilation, until the present period when rights are being exerted over this landscape of multiple meanings.

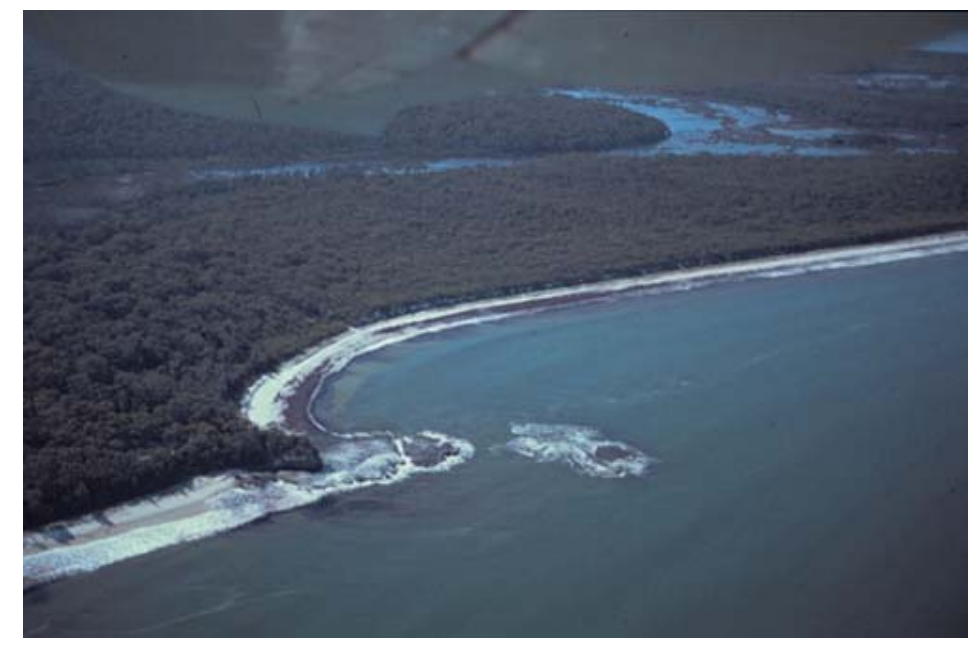

Figure 3: Red Point, Jervis Bay - Marine park sanctuary zone and location of customary fishing. (Photo: Sue Feary).

The campaign to stop the Navy's proposal was successful, opening the way for Stage 1 of Jervis Bay National Park to be declared in 1995. Three years later, the NSW Government introduced changes to the National Parks and Wildlife Act 1974 to allow for Aboriginal ownership of selected national parks in NSW. Mutawinji National Park near Broken Hill in the far west of the state was the first to be handed back to Aboriginal owners and currently there are four national parks now in Aboriginal ownership in the state (National Parks and Wildlife Service, 2006). ${ }^{7}$ Since 1995 there have been extensive negotiations between NPWS and the local Aboriginal community concerning joint management of Jervis Bay National Park. During negotiations it became apparent to myself ${ }^{8}$ and other NPWS staff that the Aboriginal community did not share our view of the advantages of owning a national park at Jervis Bay. Reasons

\footnotetext{
${ }^{6}$ The prominent headland (called Red Point) seen in the photo in Fig. 3 is used by Aboriginal fishermen to spot fish today. The presence of archaeological sites on the headland and locally held memories of its use in historical times indicates that it has been used for fish spotting for many generations.

${ }^{7}$ Several other national parks are co-managed through a variety of arrangements but the land tenure has not changed.

${ }^{8}$ At the time I held an Area Manager position in NPWS, based at Nowra. Jervis Bay NP and Jervis Bay Marine Park were included in the protected areas for which I had overall responsibility.
} 
for this are complex and are discussed elsewhere (Feary, 2001; Lowe and Davies, 2001), but one important reason is that conservation objectives of western society are not necessarily consistent with the Aboriginal worldviews of land management. Although traditional laws, religion and custom underpinning relationships with the land, embedded in what is now commonly known as 'caring for country' have synergies with western scientifically based conservation, a growing body of literature is demonstrating some significant differences (Adams, 2004; Young, 2001; Adams and English, 2005; Langton 1998).

A senior Aboriginal woman from Jervis Bay explained to me that land was important for three things - a place to look after, a place to live in and a place from which to derive economic benefit (Feary, 2001). While joint management offers opportunities to look after country, in NSW at least, protected area legislation places restrictions on Aboriginal owners living in a national park and on deriving economic benefit from it through commercial exploitation of its natural resources. A local example of this tension occurs at the location shown in Fig. 3. As well as being a place where Aboriginal people traditionally fished, Red Point contains some of the most significant seagrass beds in NSW. It is a designated Sanctuary Zone under the Zoning Plan for Jervis Bay Marine Park ${ }^{9}$ and all fishing is banned. This causes dilemmas for the local Jerrinja people, who although broadly supportive of protecting fish stocks, see the Sanctuary Zone as an infringement of their rights as original owners to earn a living from the sea in this location.

During my PhD research I came across many similar statements of ambivalence towards, rather than an outright rejection of, protected area principles. Quotes from two Aboriginal men from the Riverina whom I interviewed in 2005 are presented here as examples:

\section{A national park is a white man's way, may not be a bad thing, but could do without chucking ablanket over everything.}

\footnotetext{
${ }^{9}$ Application of the NSW Marine Parks Act 1997, although not extinguishing native title, makes no special dispensation for it. The Act currently has no formal avenues for joint management with Aboriginal owners.
} 
The national park is a good thing, but it places too many restrictions on what people can do. It would be better to allow activities to occur e.g. four-wheel driving, firewood collection, but make sure they are properly policed [adequate law enforcement]

Prohibitions on 'taking' anything from a protected area for the purposes of commercial gain limits the capacity of Aboriginal people to derive economic independence through joint management. Nevertheless, there are examples of Aboriginal communities, which although not entirely economically independent from outside financial supports, have been empowered by collaborating with conservation agencies. Ecotourism businesses stand out because they represent a melding of Aboriginal and western worldviews on the natural environment. They enable culture to be maintained through visiting places, working on country and passing on knowledge to the next generation. Importantly, they also provide a space for Aboriginal people to share their culture with non-Aboriginal people in a natural environmental setting.

Umburra Cultural Tours is an ecotourism enterprise based on guided tours of two jointly managed sacred mountains - Biamanga and Gulaga (see Fig.1) on the south coast, owned and operated by Aboriginal people from the old Aboriginal Reserve at Wallaga Lake on the NSW south coast. The operation does not always run smoothly and tours are sometimes late or cancelled at short notice. But few tourists complain because the experience of walking through the forest among the huge granite tors and listening to the evocative stories of the Dreamtime more than compensates for imperfect logistical planning. The business is not always profitable but it brings many other benefits that are intangible and non-financial. Being an integral part of the Aboriginal community and staffed by its members ${ }^{10}$, Umburra imparts a strong sense of community pride that extends far beyond the business. The knowledge holders who run the tours are proud to tell the stories of the mountains to tourists and want to share the sacredness of the mountains with non-Aboriginal people.

Aside from ecotourism, most other forest-based economic development, no matter how benign, invariably involves resource exploitation in some form. The arts and crafts industry often uses parts of trees; land rehabilitation needs seed to be collected and the

\footnotetext{
${ }^{10}$ Umburra Cultural Tours operates out of the cultural centre just outside of Bermagui, which is open every day and contains displays of Aboriginal arts and crafts and history and is surrounded by a bush tucker garden.
} 
commercial bush foods market requires harvesting of plants. At the other end of the spectrum, harvesting timber for sawlogs and wood fibre involves major resource exploitation. The remainder of this paper explores three engagements between Aboriginal society and the forest sector at the extractive, commercial end of the spectrum - forest heritage as business; Aboriginal engagement with the plantation industry and an Aboriginal owned sawmilling operation on Cape York.

\section{Forest use and Aboriginal people}

Use and management of all native forests was once subject to Aboriginal law and custom that recognised forest landscapes as both sentient beings and a resource to be utilised. Today, the majority of native forests are in public ownership (Dargavel, 1995) and apart from forests set aside as protected areas or for other reasons, commercial timber production forests comprise a major proportion of crown-owned forest land. As managers of large tracts of public land, the involvement of forest industries in land rights, native title interests and social justice is inevitable.

Natural forests, and increasingly, planted forests support viable industries that contribute 1\% to Australia’s Gross Domestic Product (GDP) (National Forest Inventory, 2003). Like many other countries, contemporary management of timber production forests in Australia is underpinned by the principles of sustainable forest management (SFM). These principles recognise that the values of forests go beyond that of economic, to embrace their intrinsic values (Nash, 1989), as well as those constructed by society (Williams, 2002). The intergovernmental meeting of the World Commission on the Environment and Development (WCED) held in Rio de Janeiro in 1987, was largely responsible for the move away from 'sustained yield' which maximised economic returns, to sustainable forest management (Wiersum, 1995). Sustainable Forest Management in tandem with movements for social justice and land rights for indigenous people worldwide has opened the way for Aboriginal voices to be heard. Geographer Richie Howitt argues that the presence of indigenous voices in forestry discourses has broadened the debate beyond forest ecology and sustainable use to include justice, history and rights (Howitt, 2004). Forestry, as a major land manager is therefore placed firmly in the social justice agenda in Australia and across the world's forested landscapes. 
Various consultative processes have demonstrated Aboriginal people's interest in participating in contemporary commercial forestry in Australia. Anthropologist Scott Cane undertook a review of Aboriginal attitudes to forestry as part of the Resource Assessment Commission's inquiry into the Forest and Timber Industry (Cane, 1990). In the late 1990s Aboriginal views were canvassed during the public consultation process for the Regional Forest Agreements ${ }^{11}$ (Buchy and Hoverman, 1999; Black et al., 2003) and most recently through the consultative workshops undertaken during development of a National Indigenous Forestry Strategy by the Commonwealth Government (BDO Consulting (SA) Pty Ltd, 2004). Reports on these processes have shown Aboriginal interests to be eclectic - ranging from a desire for employment in the mainstream as individuals; to growing and harvesting trees on Aboriginal land; using forest products for the arts and crafts market; as a source of food and medicine; through to noneconomic customary use by a local community. Generally though, the desired objective of Aboriginal people was found to be economic independence through viable, sustainable utilisation of forest resources while respecting socio-cultural obligations to care for the land.

These obligations can be expressed in a variety of ways - sometimes meaning protection of the cultural heritage of the forests, as expressed by tangible archaeological sites, or intangible spiritual, religious values; sometimes meaning mechanisms for maintaining and passing on culture. In other cases it meant doing business in a way that was culturally appropriate in terms of such matters as kinship obligations and respecting other people's traditional country.

The capacity to recognise and respond to Aboriginal people's customary obligations at the local level is a major challenge facing forest industries if they wish to participate in overcoming Aboriginal social and economic disadvantage. Recent research into Indian economic development in the United States has demonstrated that an appropriate 'cultural match' between the type of economic development and the nature of localised Aboriginal governance can lead to success (Cornell and Begay, 2003). There is not time

\footnotetext{
11 Regional Forest Agreements (RFAs) are 20 year agreements between the forestry industry and State and Commonwealth governments to give certainty about the availability of timber and to reduce conflict between the timber industry and conservation groups. There were 12 RFA processes between 1996 and 2001 and 11 have been completed although not all were signed off (Mobbs, 2003).
} 
in this paper to explore this concept in detail but the diversity (although this is not always recognised) that characterises both Aboriginal society and forestry lends itself to finding appropriate cultural matches.

It is also important for forest industries and the western economy more generally, to develop an awareness of the great complexities at the interface of Aboriginal culture and modernity. In Australia, as with settler societies more generally, being disadvantaged is often socially constructed by both non-Aboriginal and Aboriginal people as being synonymous with Aboriginal cultural identity. Overcoming disadvantage through economic development can be, therefore, tantamount to an undermining of culture (Martin, 1995; Foley, 2006).

\section{Forest heritage as business}

Although concerns have been raised about the narrow definition of cultural heritage i.e. tangible evidence of past occupation, adopted by commercial forestry agencies (English, 2004; Sculthorpe, 2005), surveys for archaeological sites are becoming increasingly significant as an income stream for many Aboriginal organisations in those states with strong environmental and heritage protection legislation. In NSW over the last thirty years a sizeable industry has built up around archaeological investigations in the context of environmental impact assessment. The Department of Environment and Climate Change has statutory responsibility for protection of Aboriginal objects and places in NSW. The Department's policies and guidelines for Aboriginal consultation require developers to consult widely with Aboriginal consultation and to involve local Aboriginal people in field surveys. This almost always results in developers providing short-term paid work to Aboriginal people to participate in heritage surveys and assessment. Over the last decade or so, this work has become a significant source of income for Aboriginal organisations, most of whom now have identified Heritage Officers with varying levels of training and expertise.

Forest NSW (formerly the NSW Forestry Commission) is responsible for managing timber production forests in NSW. Their policies for managing Aboriginal cultural heritage require clearance surveys prior to logging and road construction and maintenance (Forests NSW, 2005). In the Eden region, carrying out pre-logging surveys is an important revenue stream for the Eden Local Aboriginal Land Council. Their Sites 
Officer has been employed for approximately seven years and is funded through the proceeds from undertaking heritage surveys for government departments and private developers. Currently it is fruitful enough to employ him and seven other part time workers and Forests NSW is a significant client. The business has been possible for a number of reasons, including the right 'cultural match'. In reality, the situation is far more complex, with the partnership strongly influenced by personal commitments by Forests NSW local staff, long historical associations between Aboriginal people and the local timber industry as discussed previously, and a stable Land Council arising from strong leadership situated in a family with traditional ties to the area.

Another aspect of forest heritage as business relates to different constructions of the value of archaeological sites. Site surveys require a certain level of skill that the Eden Sites Officer has acquired through some formal training but mainly from working with archaeologists. During an interview for my $\mathrm{PhD}$ research the Sites Officer indicated that archaeologists and Aboriginal people don’t necessarily place the same value on sites:

[in regard to consultant archaeologists' technical reports].... half of it is scientific jargon that we don't understand and don’t need to know. Aboriginal people basically know there is a site there, its recorded and through the system, that's all we need to know

Recognition that archaeological sites are important to Aboriginal people and archaeologists for different reasons has enabled the business to flourish on the basis of Aboriginal people's own construction of the cultural value of archaeological sites. It is one that is not premised on academic qualifications or high levels of technical expertise encompassed in the discipline of archaeological science (Smith, 2000). Broadening the domain of cultural heritage management beyond specialists has not only provided an opening for Aboriginal people to participate, it has created economic opportunities based on customary associations with forest landscapes.

\section{Engagement with plantations}

With the recognition of the multiple values of forests, the future of timber and wood pulp production in Australia now lies with softwood and hardwood plantations and a concomitant emphasis on private investment as the driving force in the industry (Howard, 2004) although there are a range of social and environmental issues yet to be 
resolved in regard to the expansion of plantations (Gerrand et al., 2003). Aboriginal people are proportionally well represented in rural areas and are seemingly well placed in some areas to enter the workforce and also to enter into partnerships with the private sector to provide land for growing trees. Research for my $\mathrm{PhD}$ revealed interesting insights into the associations between the plantation component of the forest sector and Aboriginal people. Importantly, plantations have the capacity to meet some of the cultural objectives of Aboriginal people, as well as providing employment and business opportunities in the market economy.

Aboriginal people interviewed were quite strong advocates of plantations, not only as financial investments but because they believed they are good for the environment. Research interviews with Aboriginal people at Esperance in southwest Western Australia demonstrated perceptions of strong links between growing trees and caring for the land:

My people have a cultural responsibility to look after the land and plantations are a way of doing it.

Esperance has always been just farming, so there's a lot of flat land around here so by putting the trees back you are also helping the environment.

Support for plantations also came from very different circumstances at Weipa on Cape York Peninsula, where large scale bauxite mining since the 1950s has removed native forests and dramatically altered the landscape. Aboriginal people are working with CSIRO and the Queensland Government in establishing plantations on mined land. Aboriginal people I interviewed indicated that plantations are important for restoring ecological health to their traditional lands:

The land needs to be in good condition when handed back after mining. That's why we are growing sandalwood, to make the land healthy.

In 2004, one of the several plantation companies operating in southwestern Australia contracted a local Aboriginal group to undertake land management work in their Tasmanian blue gum plantations near Esperance. There is a severe skill shortage in this 
region and in the knowledge that many of the plantations will be ready for harvesting in 2008, the company is providing training and work opportunities to encourage Aboriginal people to join and stay in their workforce. Currently the work is intermittent and involves weeding, fencing and erecting signs at a number of the plantations. Aboriginal people are interested in increasing their participation, but there are barriers of stereotypes to overcome. Because plantation forestry is firmly in the mainstream economy and investment driven, there is little room for accommodating difference, whether it is time off to attend a relative's funeral or lack of education and skills. However, local plantation owners are making an effort to engage with Aboriginal people, as reflected in the following two quotes by a plantation forester from southwest Western Australia:

Generally, they [the Aboriginal people] do a reasonable job. Generally it takes longer than if we employed normal contractors, but by the same token, they do a pretty good job I reckon.

[In] going out of your way to employ someone whom you nomally wouldn’t [Aboriginal people]... [you] could get work done more efficiently if you got people with more training and more equipment.

So while there seems to be a future for Aboriginal people in the plantation industry insofar as plantations can be accommodated in the worldview of customary land management, the mainstream component requires mechanisms to raise the capacity of a potential Aboriginal workforce and overcome prejudice in the industry.

\section{Sawmilling on Cape York Peninsula}

A sawmilling operation near Weipa on the western side of Cape York Peninsula in Far North Queensland is an example of a successful forestry business connected to the mainstream economy but situated in an Aboriginal landscape in the both the physical and cultural sense. Weipa contains the world's largest bauxite mine and discovery of the economic value of bauxite deposits in 1955 brought profound changes to the land and its people (Howitt, 1992). The Aboriginal settlement of Napranum is close to Weipa and comprises approximately 700 people of Aboriginal, Torres Strait and South Sea Islander descent (Suchet, 1996). It occupies the site of a previous Presbyterian Mission and 
many older people living at Napranum have memories of the mission, including of the sawmills that operated there.

Mining and forestry narratives are inexorably intertwined at Napranum but unlike fifty years ago, Aboriginal people are now in a position to negotiate favourable outcomes for their community rather than be overwhelmed by the solely economic goals of largescale resource extraction. Until recently, Darwin Stringybark forests in the mining lease were cleared and burnt to allow access to the bauxite layer beneath (Annandale and Taylor, 2006). Following negotiations between the mining giant Comalco, the Queensland Government and local Aboriginal communities, a new Indigenous owned business called Nanum Tawap ${ }^{12}$ was established in the late 1990s to run a small sawmill and concrete block production plant at Napranum.

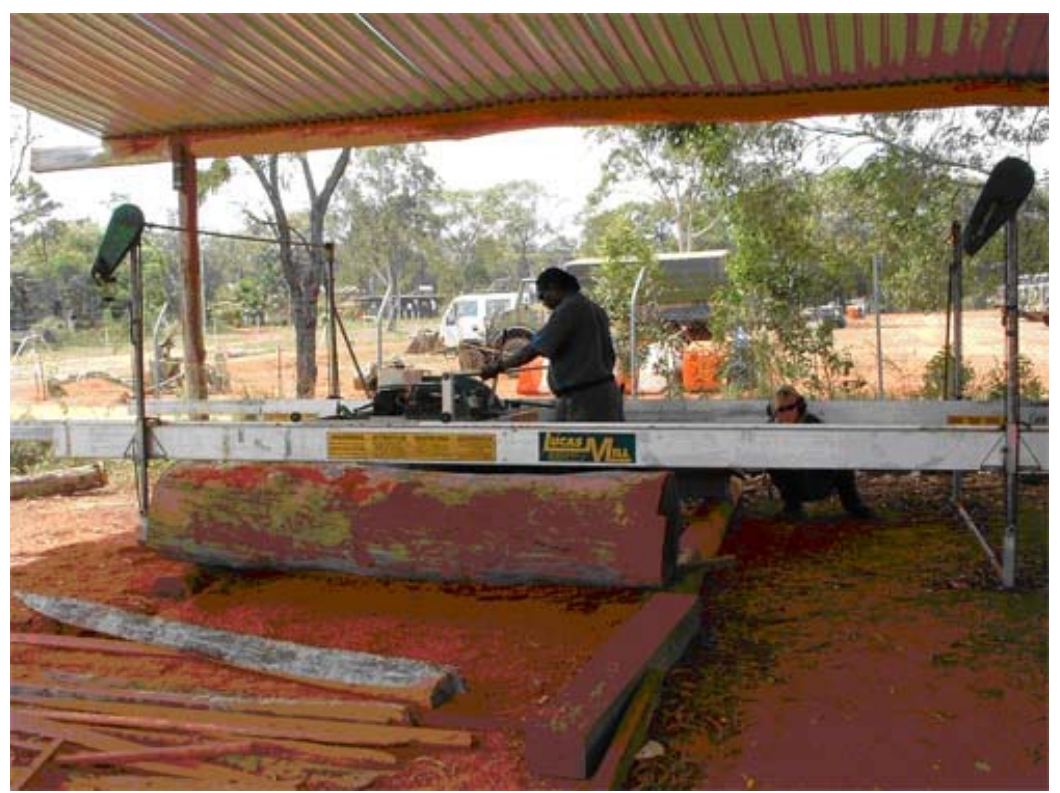

Figure 4: Operating the mobile sawmill at Nanum Tawap, Cape York, 2005. Photo: Queensland Govt.

Economically valuable timber is identified and felled prior to clearing for mining and the trees are processed in the sawmill for local use and export. The mill has a nonAboriginal manager and employs about five local Aboriginal men, who also occasionally work at the adjacent concrete block production plant.

Given the notable failure of many business enterprises in remote Aboriginal communities, Nanum Tawap stands out as an example of what can be achieved when customary units of negotiation and governance (through the five traditional clan

\footnotetext{
${ }^{12}$ The Nanum Tawap management committee comprises representatives of the 5 clan groups whose traditional lands are currently covered by Comalco's mining lease.
} 
groups) are given the opportunity and capacity to operate in a contemporary market environment.

An important decision made by the committee was to separate the sawmill business from other community business and social issues. A Queensland Government forester involved in assisting the Napranum community to establish and operate the sawmilling business summed it up this way during an interview I had with him:

One of the things that was actively worked on and identified by community leaders was that the sawmill was business... that they don’t want to mix all other elements of the social environment with that because that's what always happened in the past and the business failed. . .it's been very conscious, there's a big line there.

This separation is not only administrative; it is also reflected by the high fence and the gate that separate the sawmill from the rest of the settlement. On entering the fenced Nanum Tawap compound through a gate, there is a strong sense of being in a work place, and rules relating to the work place such as safety are evident. Symbolically, it is stepping out of the community space with all its kinship obligations and responsibilities, into the workplace where responsibility is to the boss and to the business.

How culture and business combine at Napranum is not through having culturally appropriate work, or work that makes special dispensation for what tends to be imagined as Indigeneity e.g poor work ethics, accepting cultural factors as a legitimate reason for absence from the workplace or production of substandard goods. Instead, culture is recognised at higher levels; in the administrative and management structures of the business, where Aboriginal people have real power in decision-making and where traditional clan territories are recognised and respected. This arrangement was articulated by the same forester during an interview:

I guess it's more accurate to say that the operational side of Nanum Tawap is removed as best they can from that [social and cultural life], but the broad policy direction is not. 
Nevertheless special dispensations are made in this workplace, as a way of achieving the goal of a viable business enterprise, including incentives that reflect the wishes of the local workers, in this instance, white goods. There is also a pragmatism that recognises the lives of Aboriginal people in remote areas are different, as stated by the non-Aboriginal sawmill manager during an interview:

We know we’ve got a real problem with our staff - very illiterate, live in an insular society here. No life experience that we [white people] take for granted. Changing these attitudes is a challenge; have to have management that understands these problems. There will have to be a lot of life education. We've got to be that much more patient.

Aboriginal workers themselves are acutely aware of the barriers resulting from their having only limited experience in the workforce:

[in relation to working at the sawmill] some do, but they don’t know how to do it. Don't know how to work; they are a bit shy from trying. ${ }^{13}$

The complex decisions facing Aboriginal people when distinguishing between 'work' and 'culture' were revealed in the Nanum Tawap Management Committee's response to a recent evaluation of the timber resource. The evaluation indicated that the sawmill's capacity would need to be substantially increased to maximise economic returns from timber salvage operations (Annandale and Taylor, 2006). A feasibility study was undertaken to explore options for business models that would produce the best outcomes for the Aboriginal communities of Napranum and its neighbours, Mapoon and Aurukun. These options were considered by committee members and in a meeting in 2005, they opted for a business model that would maximize local employment rather than economic returns. Three small sawmills, one in each community would employ more people and require less technical skills, but would have a reduced profit margin. By contrast a single, large mill would bring in high economic returns but employ less people and require high levels of technical expertise. The higher priority often given to building social capital (through jobs) and allowing power to remain at the local level,

\footnotetext{
${ }^{13}$ This is a direct quote from a young Aboriginal man employed by Nanum Tawap. The last sentence is a reference to the shame that Aboriginal people sometimes feel from lacking skills and education relative to non-Aboriginal workers.
} 
over maximizing economic returns is an significant factor in decisions made by Aboriginal people in the milieu of contemporary business management.

Life at Napranum has changed for its Aboriginal inhabitants, with a cash economy, close proximity to Weipa township and easy access to alcohol (Napranum is dry but alcohol is easy to come by) but attachment to and knowledge of the land remains as an omnipotent force (Suchet, 1996). Many, probably most, Aboriginal people at Napranum don't like bauxite mining because it damages the land and results in denial of access to many parts of their country. However, reasserting links to the land, even if it is damaged and looking after unmined country is of overwhelming importance. NRM is undertaken through the Nanum Wungthim Land and Sea Management Centre, whose rangers survey the forests for significant culturally modified trees prior to mining (McNaughton and Morrison, 2005), maintain the camping grounds, undertake land management activities and keep culture alive through teaching knowledge to young people. Links between Nanum Tawap, Nanum Wungthim and the rest of the community at Napranum are fluid and perceived in many different ways within the community, but links between looking after the land and using its resources in a contemporary market economy remain strong.

\section{Conclusion}

The case studies used in this paper have revealed a broad spectrum of forest-based activities involving Aboriginal people, from conservation through to the full commodifaction of forest products. Involvement of Aboriginal people in conservation of nature and culture contributes to social justice goals through retaining cultural traditions and recognising the contribution of indigenous knowledge to land management. However, conservation as it is practised in the western world will always be inhibited in what it can deliver to Aboriginal people in a direct economic sense. Increasingly managers of public land outside the purely conservation paradigm, including managers of native timber production forests, are subject to Aboriginal interests and rights, through native title, land rights and social justice movements. While the conservation models of co-management are possible over timber production forests, other avenues such as the cultural heritage business described above are also attractive. In addition to enabling an ongoing connection with the cultural values of the forests, enterprises such as these can be financially lucrative. Importantly, the partnerships 
fostered between forestry managers and Aboriginal people can go beyond the purely business to one where forestry operations take account of Aboriginal cultural values.

Plantation forestry is less involved in land rights and native title because the majority of plantations are on private land. However, labour shortages, the need for land to grow trees and a desire by plantation owners to be good corporate citizens are driving an agenda for enhancing Aboriginal participation in plantation forestry. The Western Australian examples have shown that current barriers to Aboriginal people entering plantation forestry exemplify the marginalised position of Aboriginal people in our society including low levels of education and skills and highlight lingering prejudices based on negative stereotypes. The Cape York example demonstrates that Aboriginal owned forests potentially offer good opportunities for a melding of customary and western ideologies that deliver triple bottom line benefits, but good governance and appropriate partnerships with government agencies are essential.

Social justice for Aboriginal society includes the right to derive economic benefits from natural resources as well as the right to have them protected as part of customary lands. The challenge facing forest industries, conservation agencies and Aboriginal people is to establish processes that recognise the pluralistic nature of the forest sector and that 'one size does not fit all'. Aboriginal people at the local level may opt for a purely economic activity, or a purely 'caring for country' activity or various combinations of the two. The decision taken will depend on many factors including historical legacies such as previous employment in the timber industry and the general health, wellbeing and capacity of the local Aboriginal community.

\section{Acknowledgements}

Thanks are extended to Heather Goodall for inviting me to present a paper at the Landscapes of Meaning Symposium at the University of Technology Sydney in October 2006. I am grateful to the two anonymous referees for their constructive comments on a draft of the paper.

\section{References}

Adams, M., (2004) Negotiating nature; Collaboration and Conflict Between Aboriginal and Conservation Interests in New South Wales, Australia, Australian Association for Environmental Education, 20(1): 3-11. 
Adams, M. and English, A. (2005) 'Biodiversity is a whitefella word' ; changing relationships between Aborigines and the New South Wales National Parks and Wildlife Service, In The Power of Knowledge The Resonance of Tradition, (Eds.), Taylor, L., Ward, G., Henderson, G., Davis, R. and Wallis, A., Aboriginal Studies Press, Canberra, pp. 86-98.

Altman, J. and Hinkson, M. (eds.) (2007) Coercive Reconciliation : Stabilise, Normalise, Exit Aboriginal Australia, Arean Publications, North Carlton, Victoria.

Anderson, J. (1984) Between Plateau and Plain: Flexible responses to the varied Environments in Southwestern Australia, Occasional Papers in Prehistory No. 4, Research School of Pacific Studies, ANU.

Annandale, M. and Taylor, D. (2006) Forest Futures - Aboriginal Timber and Forestry Enterprises on Cape York., In Forestry for Aboriginal people. Proceedings of Technical Session 130, IUFRO, Brisbane 2005, (Ed.), Feary, S., ANU Fenner School of Environment and Society, pp. 49-59.

Austin-Broos, D. (2005) Introduction, In Culture, Economy and Governance in Aboriginal Australia. Workshop Proceedings, 30-1 November 2004, University of Sydney, (Eds.), Austin-Broos, D. and Macdonald, G., Sydney University Press, Sydney, pp. 1-6.

Baker, R., Davies, J. and Young, E. (2001) Managing Country. An Overview of the Prime Issues, In Working on Country, (Eds.), Baker, R., Davies, J. and Young, E., Oxford University Press, Melbourne, pp. 3-22.

BDO Consulting (SA) Pty Ltd. (2004) Opportunities and barriers for greater Aboriginal involvement in Australia's forestry industry, Commonwealth of Australia, Canberra.

Black, A., Baines, P. and Bekle, H. (2003) Towards a framework for Consultation and for Input of Aboriginal Knowledge Pertinent to Ecologically Sustainable Forest Management at a Regional Level, Forest and Wood Products Research and Development Corporation, Melbourne.

Bowdler, S. (1983) Aboriginal Sites on the Crown- timber lands of New South Wales, Forestry Commission of New South Wales, Sydney.

Buchy, M. and Hoverman, S. (1999) Understanding Public Participation in Forest Planning in Australia: How Can We Learn From Each Other? ANU Forestry Occasional Paper 99.2, ANU.

Cane, S. (1990) Trees on the Land, Report to the Resource Assessment Commission Forest and Timber Inquiry, Canberra.

Castel, R. and Hagan, J. (1978) Dependence and Independence: Aboriginal Workers on the Far South Coast of NSW 1920-75, In Who are our enemies? Racism and the Working Class in Australia, (Eds.), Curthoys, A. and Markus, A., The Australian Society for the Study of Labour History, Sydney, pp. 158-171.

Chittick, L. and Fox, T. (1997) Travelling with Percy. A South Coast Journey, Aboriginal Studies Press, Canberra.

Cornell, S. and Begay, M. (2003) What is Cultural Match and Why is it so Important? Lessons from 14 years of the Harvard Project, Building Effective Aboriginal Governance, Jabiru, NT. Available at: <http://www.nt.gov.au/cdsa/Aboriginal_conference/web/html/papers.html> 
Cosgrove, R. (1990) The Archaeological Resources of Tasmanian Forests: Past Aboriginal Use of Forested Environments, Commonwealth of Australia, Hobart.

Dargavel, J. (1995) Fashioning Australia's Forests, Oxford University Press Australia, Melbourne.

Donaldson, S. (2006) Stories about the Eurobodalla by Aboriginal People: Eurobodalla Aboriginal Cultural Heritage Study, Eurobodalla Shire Council, and DECC.

Egloff, B. (1979) Mumbulla Mountain. An Anthropological and Archaeological Investigation, National Parks and Wildlife Service of NSW, Sydney.

English, A. (2004) Echidnas and Archaeology: understanding the Aboriginal values of forests in NSW, In Conservation of Australia's Forest Fauna, (Ed.), Lunney, D., Royal Zoological Society of New South Wales, Mosman, pp. 175-185.

Feary, S. (2001) Moving towards joint management in New South Wales: A Jervis Bay Case Study, In Working on Country. Contemporary Aboriginal Management of Australia's Lands and Coastal Regions, (Eds.), Baker, R., Davies, J. and Young, E., Oxford University Press, Melbourne, pp. 276-293.

Foley, D. (2006) Aboriginal Australian Entrepreneurs, Canberra, Discussion Paper No. 279, Centre for Aboriginal Economic Policy Research, ANU.

Forests NSW (2005) Operational Guidelines for Aboriginal Cultural Heritage Management., NSW Department of Primary Industries.

Gerrand, A., Keenan, R., Kanowski, P. and Stanton R (2003) Australian forest plantations: an overview of industry, environmental and community issues and benefits, Australian Forestry, 66(1): 1-8.

Goulding, M. and Griffiths, C. (2004) Bega Valley Aboriginal Cultural Heritage Study, Stage 3, Report to DECC and Bega Valley Shire Council.

Goulding, M. and Waters, K. (2005) Shoalhaven Local Government Area Aboriginal Heritage Study NSW. Aboriginal Historical Research. Stage 1, Report to Shoalhaven City Council.

Harris-Daishowa (Australia) Pty Ltd. (1986) Draft Environmental Impact Statement for the Eden (N.S.W.) export woodchip operation for the period 1989-2009. HarrisDaishowa Pty Ltd, including managers of timber production forests, Eden.

Howard, A. (2004) From villains to visionaries: the debate we have to have, Australian Forest Grower. Special Liftout No.69, 27(3): 1-8.

Howitt, R. (1992) Weipa: Industrialisation and Aboriginal Rights in a Remote Australian Mining Area, Geography, 77(331): 223-235.

Howitt, R. (2004) Seeing forests, trees and landscape: professional literacy, justice and ethical engagement., Forestry Education and Capacity in Indian Country. Available at http://www.es.mq.edu.au/ rhowitt/SEE_00E1.htm

Kristo, F. (nd.) Jervis Bay Paradise Lost?, Feral Ink.

Langton, M. (1998) Burning Questions. Emerging environmental issues for Aboriginal peoples in northern Australia, Centre for Aboriginal Natural and Cultural Heritage Management, Northern Territory University, Darwin.

Lowe, D. and Davies, J. (2001) Bundarwa, Berri-werri and the Bay: Traditional Rights and Bureaucratic Boundaries, In Working on Country. Contemporary Aboriginal 
Management of Australia's Lands and Coastal Regions, (Eds.), Baker, R., Davies, J. and Young, E., Oxford University Press, Melbourne, pp. 257-275.

Lunney, D. and Barker, J. (1986) Mammals of the Coastal Forests near Bega, New South Wales 1. Survey, Australian Zoologist, 23(2): 19-28.

Martin, D. (1995) Money, Business and Culture; issues for Aboriginal Economic Policy, Discussion Paper No. 101, Centre for Aboriginal Economic Policy Research, ANU.

McNaughton, D. and Morrison, M. (2005) Culturally Modified trees of the Weipa region, western Cape York Peninsula, Weipa, Comalco.

Mobbs, C. (2003) National Forest Policy and Regional Forest Agreements, In Managing Australia's Environment, (Eds.), Dovers, S. and Wild River, S., The Federation Press, Sydney, pp. 90-114.

Nash, R. (1989) The Rights of Nature, Primavera Press, Sydney.

National Forest Inventory (2003) Australia's State of the Forests Report, Bureau of Rural Sciences, Canberra.

National Parks and Wildlife Service (2006) Aboriginal co-management of parks, Available at: <http://www.nationalparks.nsw.gov.au/>

Orchard, K., Ross H and Young E (2003) Institutions and Processes for Resource and Environmental Management in the Aboriginal Domain, In Managing Australia's Environment, (Eds.), Dovers, S. and Wild River S., The Federation Press, Sydney, pp. 413-441.

Pearson, N. (2005) Peoples, Nations and Peace. Mabo Oration 3 June 2005, Available at: <http://www.adcq.qld.gov.au/docs/Mabo_Oration.rtf $>$

Pollack, D. P. (2001) Aboriginal land in Australia: A quantitative assessment of Aboriginal landholdings in 2000, Discussion Paper No 221, Centre for Aboriginal Economic Policy Research, ANU.

Rose, D. (1996) Nourishing Terrains: Australian Aboriginal Views of Landscape and Wilderness, Australian Heritage Commission, Canberra.

Routley R and Routley V. (1975) The Fight for the Forests: the takeover of Australian forests for pines, wood chips and intensive forestry, Research School of Social Sciences, ANU.

Rowley, C. (1970) The Remote Aborigines, Pelican Books, Victoria.

Sculthorpe, G. (2005) Recognising Difference: Contested issues in Native Title and Cultural Heritage, Anthropological Forum, 15(2): 171-193.

Smith, L. (2000) A history of Aboriginal heritage legislation in south-eastern Australia, Australian Archaeology, 50: 109-118.

Suchet, S. (1996) Nurturing Culture through Country: Resource Management Strategies and Aspirations of Local Landowning Families, Australian Geographical Studies, 34(2): 200-215.

Thompson, K. (1985) A history of the Aboriginal people of East Gippsland, Land Conservation Council, Melbourne.

Trigger, D. (1997) Land Rights and the Reproduction of Aboriginal Culture in Australia's Gulf Country, Social Analysis, 41(3): 84-106. 
Turvey, N. (2006) Terania Creek Rainforest Wars, Glass House Books, Queensland.

Wiersum, K. (1995) 200 Years of Sustainability in Forestry: Lessons from History, Environmental Management, 19(3): 321-329.

Williams, K. (2002) Beliefs about natural forest systems, Australian Forestry, 65(2): 81-86.

Young, E. (1995) Third World in the First. Development and Aboriginal peoples, Routledge, London, UK.

Young, E. (2001) Looking after country is men's and women's business: institutional support for Aboriginal land management, Dialogue, 20(2): 28-33. 